Prepared in cooperation with the Federal Emergency Management Agency

\title{
Flood of May 2006 in York County, Maine
}

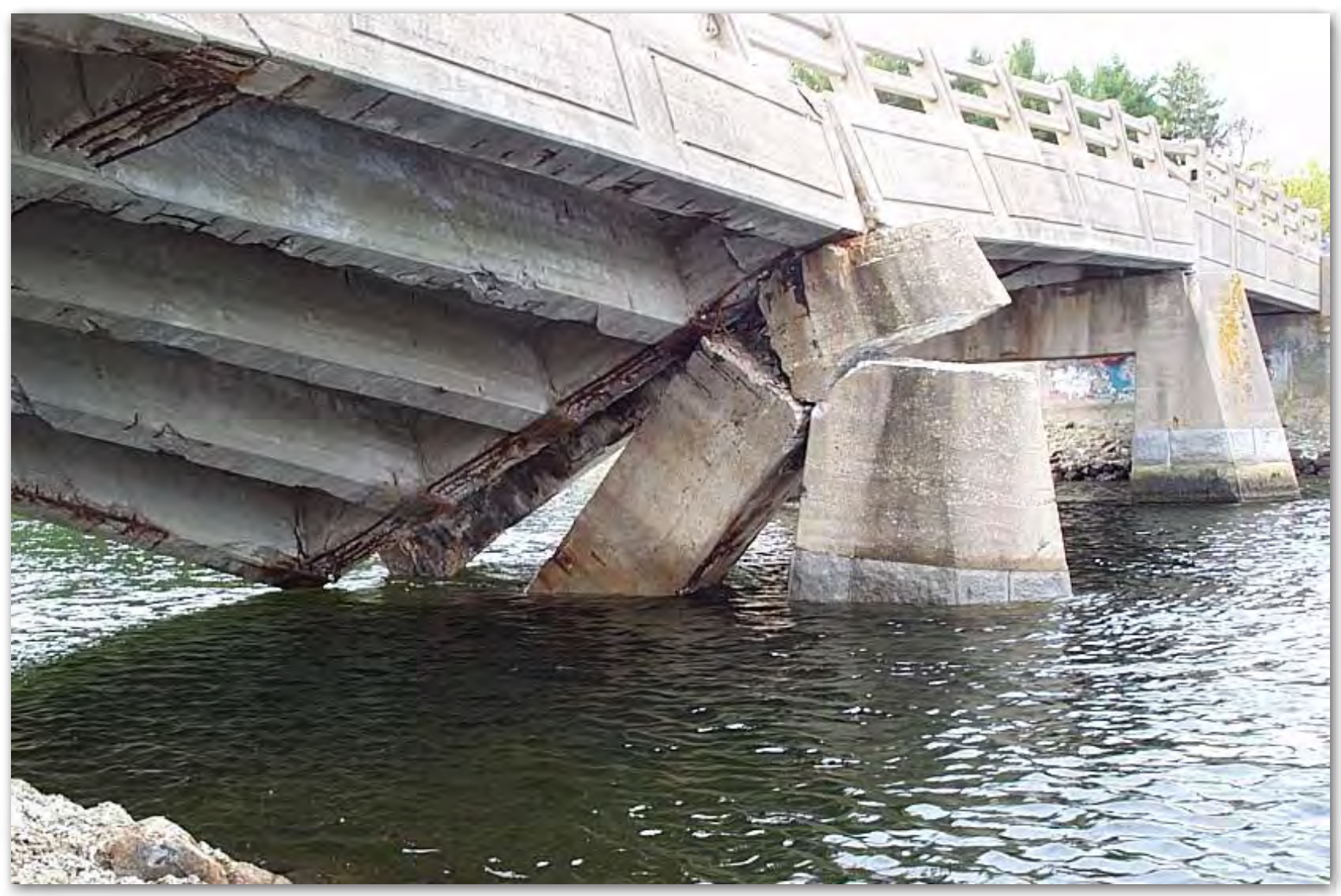

Scientific Investigations Report 2008-5047 
Cover Photo: Bridge failure on Shore Road over Cape Neddick River, York, Maine. 


\section{Flood of May 2006 in York County, Maine}

By Gregory J. Stewart and Joshua P. Kempf

Prepared in cooperation with the Federal Emergency Management Agency

Scientific Investigations Report 2008-5047 


\section{U.S. Department of the Interior DIRK KEMPTHORNE, Secretary}

\section{U.S. Geological Survey \\ Mark D. Myers, Director}

\section{U.S. Geological Survey, Reston, Virginia: 2008}

For product and ordering information:

World Wide Web: http://www.usgs.gov/pubprod

Telephone: 1-888-ASK-USGS

For more information on the USGS — the Federal source for science about the Earth, its natural and living resources, natural hazards, and the environment:

World Wide Web: http://www.usgs.gov

Telephone: 1-888-ASK-USGS

Any use of trade, product, or firm names is for descriptive purposes only and does not imply endorsement by the U.S. Government.

Although this report is in the public domain, permission must be secured from the individual copyright owners to reproduce any copyrighted materials contained within this report.

Suggested citation:

Stewart, G.J., and Kempf, J.P., 2008, Flood of May 2006 in York County, Maine: U.S. Geological Survey

Scientific Investigations Report 2008-5047, 17 p., 1 pl. (online only). 


\section{Contents}

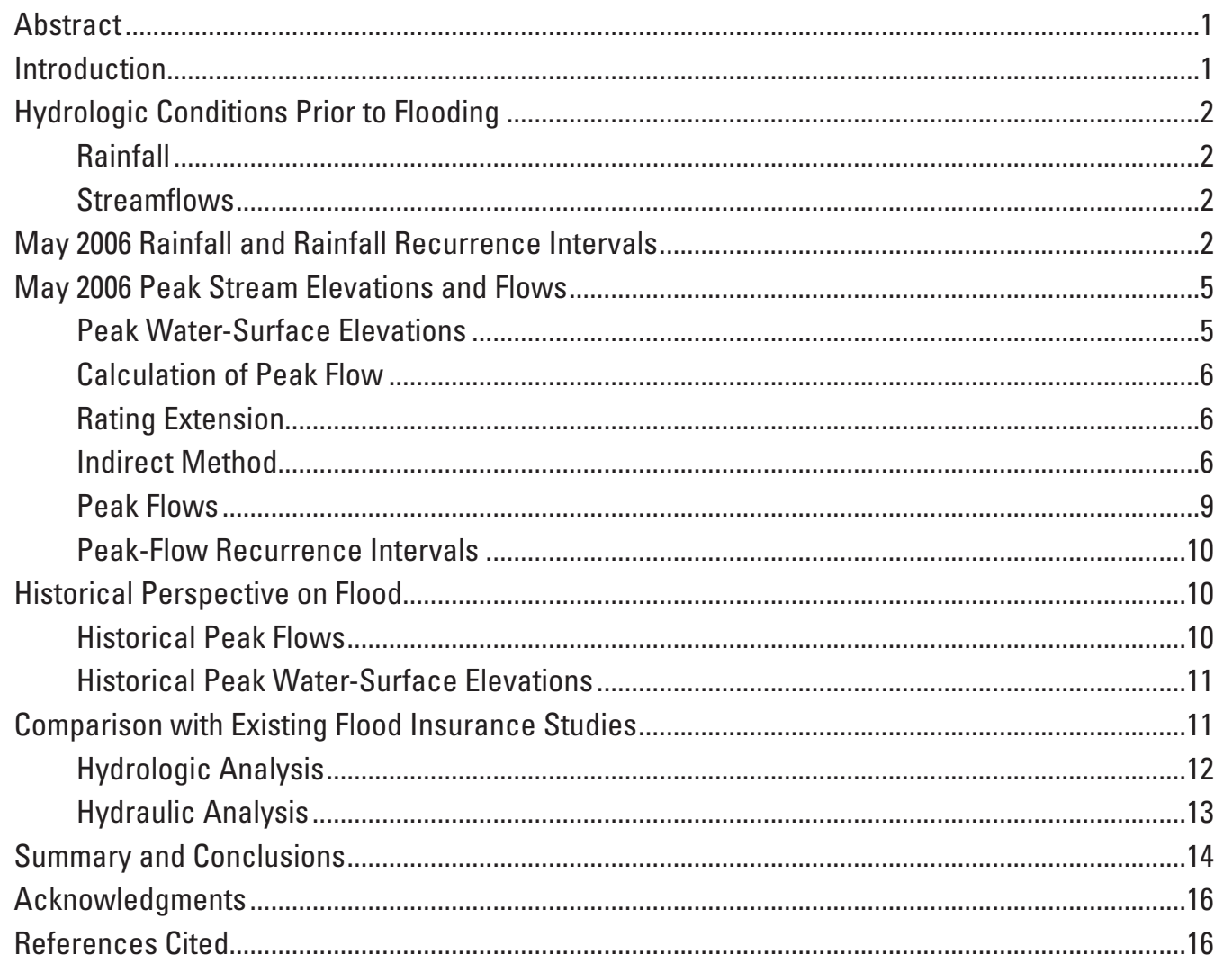

\section{Figures}

1. Map showing location of study area and total precipitation for 3-day period from May 13 through May 15, 2006, York County, Maine .........................................................

2. Map showing total precipitation for 8-day period from May 9 through May 15, 2006, York County, Maine .......................................................................................................

3. Photo showing logging road culvert failure over the Josias River, York County, Maine............5

4. Photo showing bridge failure over Cape Neddick River, York County, Maine ............................6 


\section{Tables}

1. Peak water-surface elevations for May 2006 flood in York County, Maine

2. Peak flows calculated for the May 2006 flood and peak flows for 10-, 50-, 100-, and 500-year flood recurrence intervals in York County, Maine.

3. Peak flows calculated for the May 2006 flood in York County, Maine, and peak flows from published Flood Insurance Studies for the 100- and 500-year recurrence interval events.

4. Peak water-surface elevations during the May 2006 flood and the 100-year and 500-year elevations from published Flood Insurance Studies for York County, Maine 15

\section{Plate}

1. Locations of peak water-surface elevations,York County, Maine, May 2006. Available for download 


\section{Conversion Factors}

\begin{tabular}{|c|c|c|}
\hline Multiply & By & To obtain \\
\hline \multicolumn{3}{|c|}{ Length } \\
\hline inch (in.) & 2.54 & centimeter $(\mathrm{cm})$ \\
\hline inch (in.) & 25.4 & millimeter (mm) \\
\hline foot $(\mathrm{ft})$ & 0.3048 & meter $(\mathrm{m})$ \\
\hline \multicolumn{3}{|c|}{ Area } \\
\hline square mile $\left(\mathrm{mi}^{2}\right)$ & 259.0 & hectare (ha) \\
\hline square mile $\left(\mathrm{mi}^{2}\right)$ & 2.590 & square kilometer $\left(\mathrm{km}^{2}\right)$ \\
\hline \multicolumn{3}{|c|}{ Volume } \\
\hline cubic foot $\left(\mathrm{ft}^{3}\right)$ & 0.02832 & cubic meter $\left(\mathrm{m}^{3}\right)$ \\
\hline \multicolumn{3}{|c|}{ Flow rate } \\
\hline cubic foot per second $\left(\mathrm{ft}^{3} / \mathrm{s}\right)$ & 0.02832 & cubic meter per second $\left(\mathrm{m}^{3} / \mathrm{s}\right)$ \\
\hline foot per mile $(\mathrm{ft} / \mathrm{mi})$ & 0.1894 & meter per kilometer $(\mathrm{m} / \mathrm{km})$ \\
\hline
\end{tabular}

Vertical coordinate information is referenced to the North American Vertical Datum of 1988 (NAVD 88). 


\title{
Flood of May 2006 in York County, Maine
}

\author{
By Gregory J. Stewart and Joshua P. Kempf
}

\section{Abstract}

A stalled low-pressure system over coastal New England on Mother's Day weekend, May 13-15, 2006, released rainfall in excess of 15 inches. This flood (sometimes referred to as the "Mother's Day flood") caused widespread damage to homes, businesses, roads, and structures in southern Maine. The damage to public property in York County was estimated to be $\$ 7.5$ million. As a result of these damages, a presidential disaster declaration was enacted on May 25, 2006, for York County, Maine. Peak-flow recurrence intervals for eight of the nine streams studied were calculated to be greater than 500 years. The peak-flow recurrence interval of the remaining stream was calculated to be between a 100-year and a 500-year interval.

This report provides a detailed description of the May 2006 flood in York County, Maine. Information is presented on peak streamflows and peak-flow recurrence intervals on nine streams, peak water-surface elevations for 80 high-water marks at 25 sites, hydrologic conditions before and after the flood, comparisons with published Flood Insurance Studies, and places the May 2006 flood in context with historical floods in York County.

At sites on several streams, differences were observed between peak flows published in the Flood Insurance Studies and those calculated for this study. The differences in the peak flows from the published Flood Insurance Studies and the flows calculated for this report are within an acceptable range for flows calculated at ungaged locations, with the exception of those for the Great Works River and Merriland River. For sites on the Mousam River, Blacksmith Brook, Ogunquit River, and Cape Neddick River, water-surface elevations from Flood Insurance Studies differed with documented watersurface elevations from the 2006 flood.

\section{Introduction}

Typically, rainfall is the most important factor contributing to extreme floodflows on streams in Maine. Total rainfall amounts, rainfall intensity, and spatial distribution of rainfall in a drainage basin are all important in determining the magnitude of floodflows. Antecedent hydrologic conditions (such as snowpack water equivalent, streamflow, stream-ice thickness, and soil moisture) can contribute to the intensity of a particular flood. The flood of May 10-17, 2006, was solely the result of extraordinary rainfall caused by a stalled low-pressure system that continually circulated moisture over southern Maine for more than 5 days. Many bridges and culverts were compromised in the municipalities of Cape Neddick, Wells, and Ogunquit as widespread flooding occurred in southern Maine (fig. 1). Federal disaster aid for York County was authorized under a disaster declaration issued by the President of the United States, George W. Bush.

Flood-related data are useful for many purposes. The Federal Emergency Management Agency (FEMA) and the Maine Emergency Management Agency (MEMA) require timely information on the magnitude and recurrence intervals of flooding to facilitate the mitigation processes for flood damage. Peak-flow magnitudes and recurrence intervals are used for land-use planning, including flood-plain boundary delineation and the design of bridges, culverts, and structures in the floodplain. Peak flows, peak-flow recurrence intervals, and peak water-surface elevations (associated with the peak flows) are used to establish, assess, and verify the accuracy of FEMA values for 100-year and 500-year floodplain limits and flood profiles. These values, published by FEMA in Flood Insurance Studies, are used to promote sound floodplain management by local, State, and Federal officials. Flood data also are used for other scientific purposes, including the study of the effects of climate change and land use on hydrologic regimes and ecosystems.

Documented flood data are needed for future planning and assessment, especially in the protection of life and property. During 2006-07, the U.S. Geological Survey (USGS), in cooperation with FEMA, documented and quantified a large amount of data associated with the Mother's Day flood. This report provides a detailed description of the May 2006 flood in York County, Maine. The meteorological characteristics of the May 10 to 17, 2006, storm are summarized, including rainfall amounts and their associated recurrence intervals. Hydrologic conditions (streamflow and rainfall) in the area prior to the storm are described. This report gives peak water-surface elevations for 80 high-water marks at 25 sites, and peak streamflows and associated recurrence intervals for 9 sites during the May 2006 flood. Peak flows and peak water-surface elevations in previous FEMA Flood Insurance Studies are compared to values obtained for the May 2006 flood. 


\section{Hydrologic Conditions Prior to Flooding}

The hydrologic conditions in a watershed prior to a storm can be important in determining the severity of flooding. For example, elevated streamflows prior to extreme rainfall would result in higher floodflows than would occur if streamflows had been low. Only minimal data are available on conditions prior to the extreme rainfall on May 10-17, 2006. Available data on rainfall and streamflows are presented in this section.

\section{Rainfall}

The National Weather Service operates recording and observer-operated precipitation gages throughout York County, Maine. Daily rainfall totals at these gages were compared to one another, as well as to the monthly departure from normal at individual gages. The rainfall during the month of April 2006 was less than normal (Tom Hawley, National Weather Service, oral commun., 2006).

\section{Streamflows}

Currently (2006), there are no active continuous-record streamflow-gaging stations in York County, Maine. The three closest USGS streamflow gaging stations were chosen to represent general streamflow conditions before the flood in southern York County. The station at Stony Brook at East Sebago, Maine (Cumberland County), had an April 2006 monthly mean flow of $1.98 \mathrm{ft}^{3} / \mathrm{s}$, which is less than the longterm April monthly mean flow of $5.1 \mathrm{ft}^{3} / \mathrm{s}$, based on 11 years of record. The Winnicut River at Greenland, near Portsmouth, New Hampshire, had an April 2006 monthly mean flow of $29.4 \mathrm{ft}^{3} / \mathrm{s}$, which is less than the April mean monthly flow of $60 \mathrm{ft}^{3} / \mathrm{s}$, based on 4 years of record. The Cocheco River near Rochester, New Hampshire, had an April 2006 monthly mean flow of $150 \mathrm{ft}^{3} / \mathrm{s}$, below the April mean monthly flow of $316 \mathrm{ft}^{3} / \mathrm{s}$, based on 12 years of record. These three streamflow gages indicate that overall antecedent flow conditions were below normal, based on 4 to 12 years of record and the flow calculations for April 2006.

\section{May 2006 Rainfall and Rainfall Recurrence Intervals}

Higher than normal rainfall occurring May 10 to 17 (fig. 2) - most of which was received from the Mother's Day storm on May 13 to 15 (fig. 1) - was the primary contributor to the flood. It was the wettest month of May recorded in Port- land, Cumberland County, Maine (which borders York County to the northeast) since 1871. A record precipitation amount of $12.34 \mathrm{in}$. was measured for the month, breaking the 1984 monthly record of $9.64 \mathrm{in}$. Portland had $8.52 \mathrm{in}$. more rain than normal during the month of May 2006 (National Oceanic and Atmospheric Administration, 1996). May 2006 monthly totals for Cape Neddick, Eliot, Sanford, Kennebunkport, Hollis, and W. Buxton in York County were 20.26 in., 17.86 in., 15.54 in., 14.43 in., 14.27 in., 12.63 in., respectively.

Rainfall totals from May 13 to 15 (3-day) and May 10 to 17 (8-day) are shown as lines of equal rainfall (isolines) in figures 1 and 2. These isolines were computed by the National Weather Service (NWS) using the monitoring sites shown in figure 1 and 2. Although Portland received a total of $7.04 \mathrm{in.}$ of rain during May 10-17, Cape Neddick received 15.96 in. because it was closer to the centroid of greatest rainfall (Tom Hawley, National Weather Service, oral commun., 2006).

Before rainfall started on May 10, 2006, a blocking weather pattern formed over the eastern United States. As this pattern fully developed, it enabled the continuous circulation of moisture over much of New England. Eight-day rainfalls of 12 to $14 \mathrm{in}$. were common throughout York County, Maine (Tom Hawley, National Weather Service, written commun., 2006).

Although most of the intense rainfall was received during May 13-15, the ground became saturated because of rainfall that began as early as May 9 th. After the intense rain began to taper off, flooding in rivers and streams was prolonged because lesser amounts of rainfall continued for days afterward (Tom Hawley, National Weather Service, written commun., 2006).

The Atlas of Precipitation Extremes for the Northeastern United States and Southeastern Canada (Wilks and Cember, 1993) contains maps with recurrence-interval isolines for 1-, 2-, 4-, 7-, and 10-day rainfall totals. The T-year (where T equals $100,50,25,10,5$, and 2) rainfall recurrence intervals for southern Maine were interpolated from these maps. The recurrence interval is the average period of time between rainfalls that are greater than, or equal to, a specified magnitude. As an example of recurrence interval, the 100-year rainfall is the rainfall that, on long-term average, would be equaled or exceeded once every 100 years. This means that there is a 1.0 percent chance every year that a rainfall of this magnitude will be equaled or exceeded. The 100-year rainfall totals for 2-day, 4-day, 7-day, and 10-day periods in southern Maine are 8 in., 9 in., 11 in., and 12 in., respectively (Wilks and Cember, 1993). The average rainfall, based on the National Weather Service precipitation records, received during the Mother's Day flood of May 2006 exceeded the 100-year recurrence interval for 2-day, 4-day, 7-day, and 10-day rainfall totals at many locations throughout southern York County (especially Cape Neddick, Eliot, and Sanford). 


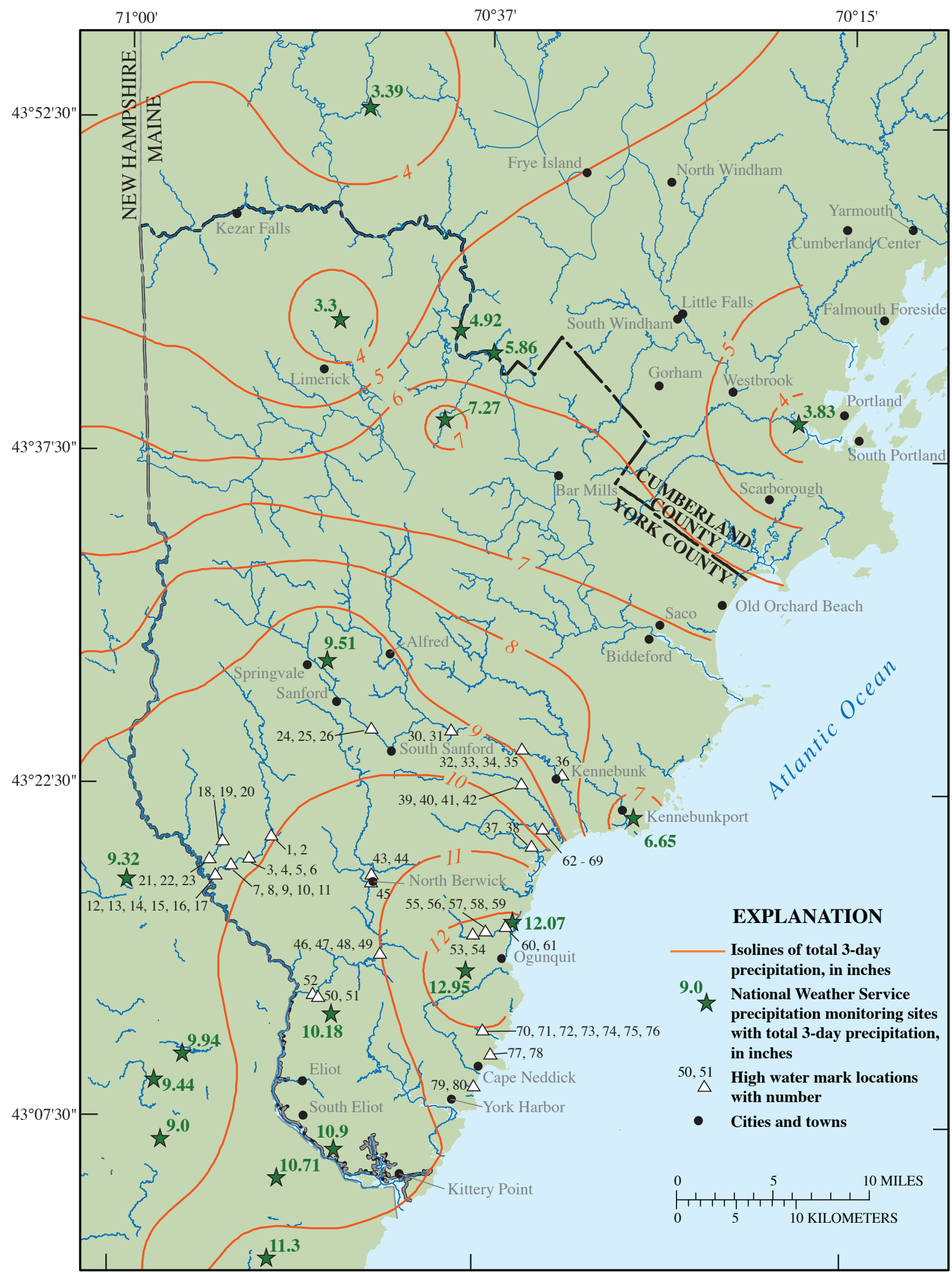

Figure 1. Location of study area and total precipitation for 3-day period from May 13 through May 15, 2006, York County, Maine. 


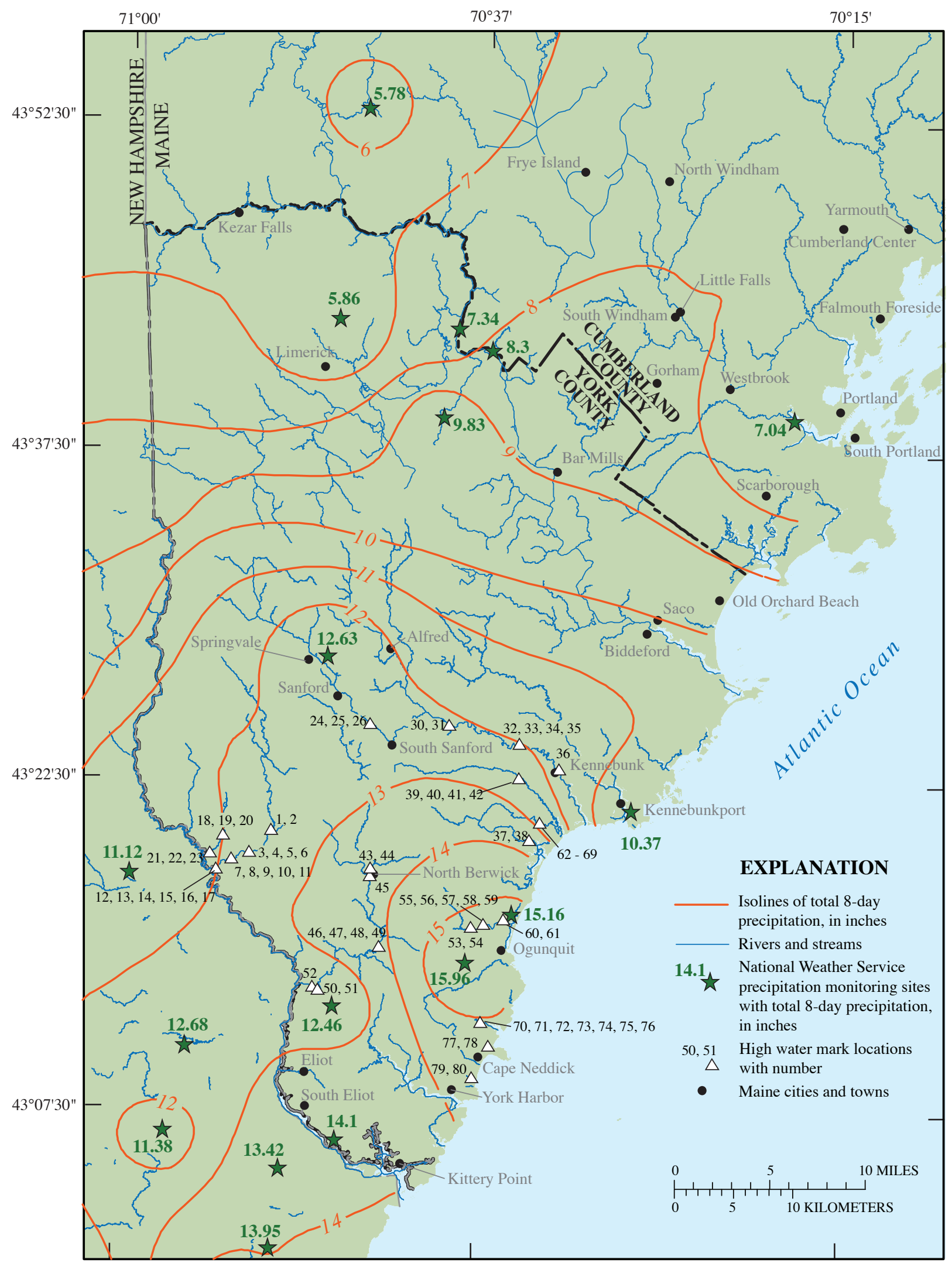

Figure 2. Total precipitation for 8-day period from May 9 through May 15, 2006, York County, Maine. 


\section{May 2006 Peak Stream Elevations and Flows}

The rain that fell in York County, Maine, during May 10-17, 2006, resulted in extreme water-surface peak elevations and peak streamflows, which are described in the following sections. The photographs in figures 3 and 4 show examples of the damages from the flooding.

\section{Peak Water-Surface Elevations}

Peak water-surface elevations were determined for 80 points at 25 sites in York County, Maine, following the May 2006 flood (table 1). The 25 site locations and 80 points are shown on plate 1 . Most of the sites are at bridges or culverts, which typically have a large effect on peak water-surface elevations. For example, bridges and culverts often cause constrictions in a stream during floodflows that result in higher peak water-surface elevations on the upstream side of the structure than on the downstream side. Because of this, both upstream and downstream peak water-surface elevations were determined, when possible. Peak water-surface elevations are based on high-water marks (fig. 1 and 2) which were identified using the techniques of Benson and Dalrymple (1967). These marks are referenced to the North American Vertical Datum of 1988 (NAVD 88). All final marks in this report were confirmed either with additional marks or corroborating evidence. The corroborating evidence generally consisted of wash lines on the bank (areas below wash lines have been scoured of leaves and other normal debris), debris in tree branches, and observations by local residents. The corroborating evidence is critical in evaluating the accuracy of a high-water mark but difficult to document. Any other available information was used in the process of evaluating the high-water marks. The locations of all the high-water marks are shown on plate 1. All of the high-water marks are located near 1 of 25 different structures. Each structure is shown on plate 1 as a inset image

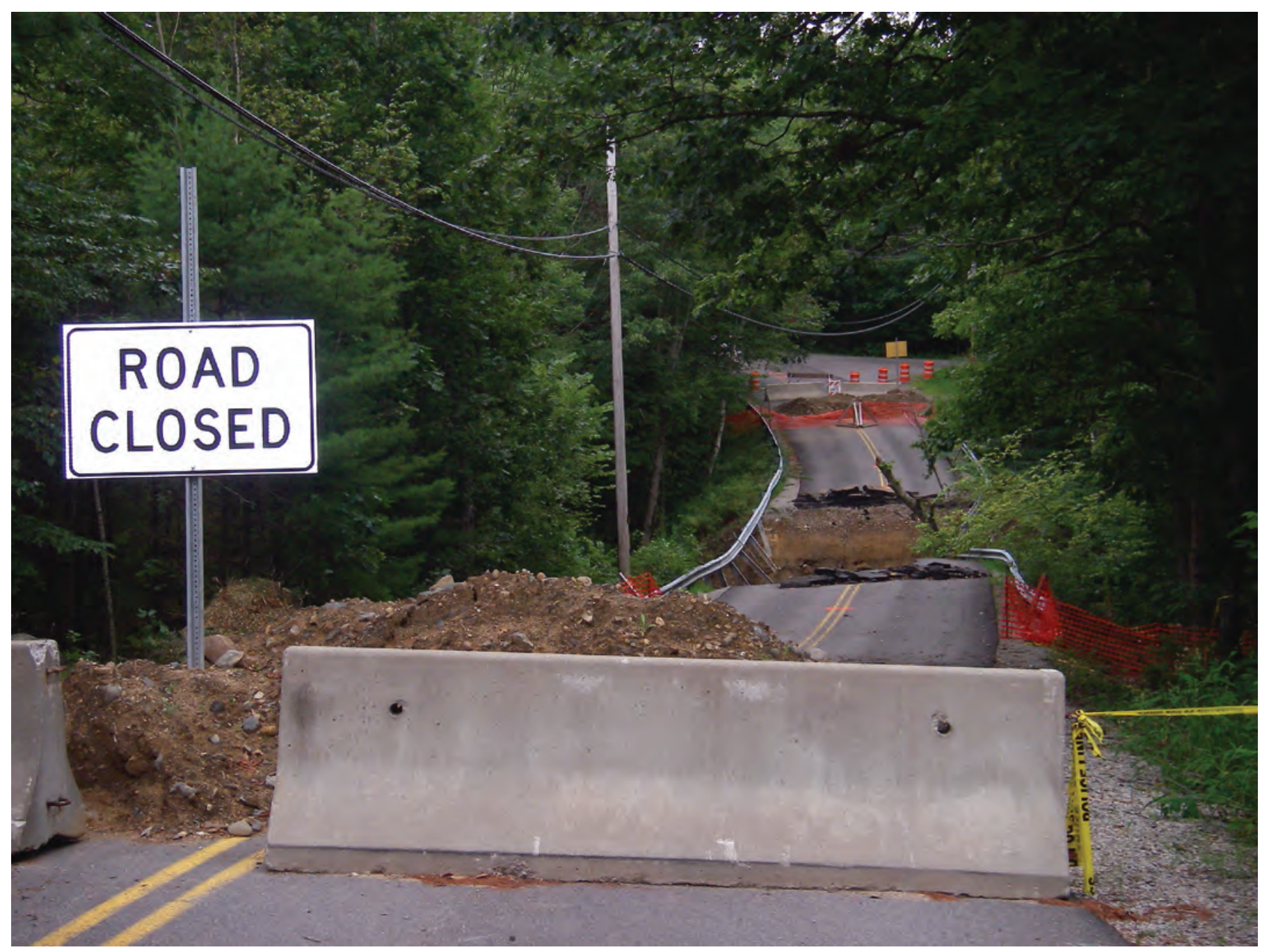

Figure 3. Logging road culvert failure over the Josias River, York County, Maine. 


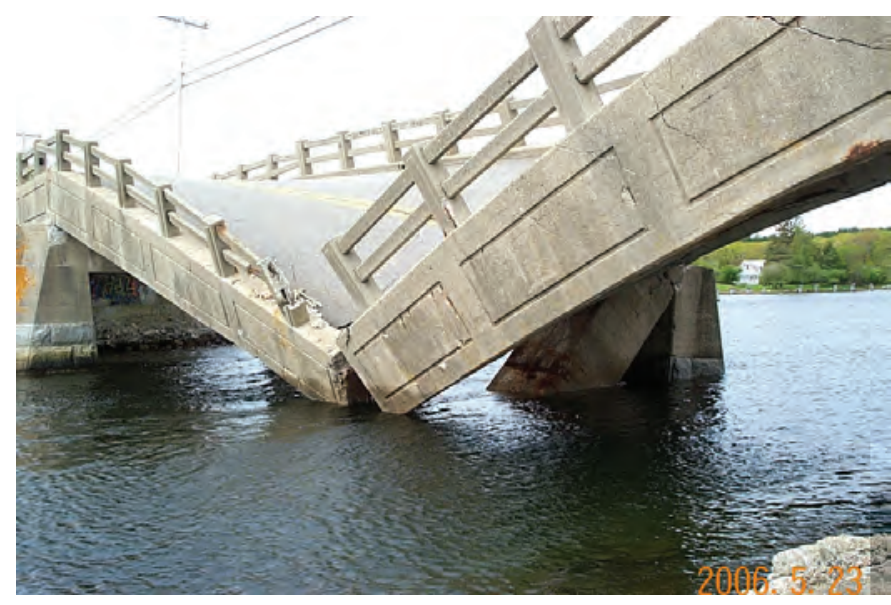

Figure 4. Bridge failure over Cape Neddick River, York County, Maine.

and labeled as an area with the corresponding site number. Three of the 22 inset images show 2 individual sites on the same image.

For an accurate evaluation of flood-peak elevation data, an understanding of the methods used to obtain them and their relation to stream profiles is needed. For example, flood elevations can be affected by water pileup on the upstream side of hydraulic structures (for example, bridges, and culverts) and by drawdown on the downstream side of these structures (Fontaine and Nielsen, 1994). To accurately interpolate peak water-surface elevations between the sites listed in table 1, further investigation and a knowledge of the hydraulics of specific streams is needed. The exact time of the peak elevation or the peak flow from the May 2006 York County, Maine, flood is not known for any of the points. Some anecdotal information was documented from observations, but further investigation and additional confirmation would be required to produce the exact dates and times of the peak flows during the Mother's Day flood of 2006.

\section{Calculation of Peak Flow}

Peak flow calculations can be made using a variety of methods. The most reliable method is a calibrated and recently confirmed relation between flows and water-surface elevations (commonly called a rating curve). If the observed watersurface elevation is higher than any previously measured for the rating curve, it may be possible to extend the curve. If a rating curve is not available, or is unreliable for extremely high flows, the peak flow can be calculated using indirect methods. Indirect methods of determining peak flow are based on hydraulic relations between flow and the geometry of the channel. A field survey is made after the flood to determine the location and elevation of high-water marks and the characteristics of the channel (Benson, 1967). Flow during the May 2006 flood was calculated for nine streams using a rating extension or indirect methods.

\section{Rating Extension}

To compute the peak flow by rating extension for the Mousam River near West Kennebunk and at Branch Brook near Kennebunk, the rating curve was analyzed by applying arithmetic processes, as well as basic concepts of open-channel flow, to available streamflow measurements. The relation of stage to flow is usually controlled by a cross section or a reach of a channel referred to as the control. Section controls exist for both the Mousam River near West Kennebunk and at Branch Brook near Kennebunk. The rating curve can be graphically represented as a straight line when plotted in logarithmic space. The graphing scale is altered by using a gage-height scale offset until the rating can be represented as a straight line. The rating can then be extrapolated beyond its calibrated range as a straight line (Rantz, 1982). This is believed to be a reasonable approach based on the stability and type of the river control for high flows at both locations.

To determine the validity of the assumption that a straight line rating extension is reasonable, the water-surface elevation scale offset was adjusted above and below the final value. The gross adjustments to the offset created changes in the calculated flow ranging from $+/-20$ to 30 percent. The adjustments can't be quantified because the graphical nature of the extension, but the interpretation was applied using hydraulic principles and the basic channel shape.

\section{Indirect Method}

One particular type of indirect method was used to determine peak flows for all streams for the May 2006 flood - the contracted-opening method. The contraction of a stream channel by a roadway crossing creates an abrupt drop in water-surface elevation between an approach section and the contracted section under the bridge. The contracted section is, in a sense, a flow meter which can be utilized to compute floodflows by use of high-water marks upstream and downstream from the contraction. The geometry of the channel and bridge are defined by field surveys.

The contracted-opening method of indirect measurements requires surveys of four cross sections and additional information on the constricting structure. The approach section is the natural, unconstricted channel upstream from a bridge (or culvert). The upstream bridge face section defines the minimum flow area of the contraction. Generally, this section is located between the bridge abutments on the upstream side of the bridge. The downstream bridge face section defines the downstream constricted conditions. The exit section is located downstream from the constriction and is used to define natural, unconstricted-channel downstream conditions. The bridge structure is defined to identify 
Table 1. Peak water-surface elevations for May 2006 flood in York County, Maine.

[Northings and Eastings referenced to Maine State Plane West, North American Datum 1983; Elevations referenced to North American Vertical Datum of 1988; Ave, avenue; BR, bridge; DS, downstream; HWM, high-water mark; I-95, Interstate 95; LE, left edge of water (when facing downstream); Num., number; R., ID, identification; river; Rd., road; RE, right edge of water; RR, railroad; Rt., route; St. street; US, upstream; WS, water-surface elevation at time of survey, not a high-water mark]

\begin{tabular}{|c|c|c|c|c|c|c|}
\hline $\begin{array}{l}\text { Point } \\
\text { ID }\end{array}$ & $\begin{array}{c}\text { Site } \\
\text { number }\end{array}$ & Northing & Easting & Elevation & Waterbody & Location, description \\
\hline 1 & 4 & 183333.8 & 2773638.6 & 249.88 & Little River & Diamond Hill Rd., US LE BR Rail \\
\hline 2 & 4 & 183325.8 & 2773624.1 & 249.70 & Little River & Diamond Hill Rd., DS LE BR Rail \\
\hline 3 & 3 & 177650.7 & 2767100.9 & 231.71 & Little River & Long Swamp Rd., US LE \\
\hline 4 & 3 & 177709.0 & 2767040.6 & 231.63 & Little River & Long Swamp Rd., US RE \\
\hline 5 & 3 & 177536.4 & 2766881.0 & 229.57 & Little River & Long Swamp Rd., DS LE \\
\hline 7 & 2 & 175493.3 & 2762968.2 & 194.98 & Little River & Ridlon Rd., US LE 1 \\
\hline 8 & 2 & 175466.9 & 2762881.6 & 194.24 & Little River & Ridlon Rd., US LE 2 \\
\hline 9 & 2 & 175556.0 & 2762847.4 & 195.00 & Little River & Ridlon Rd., US RE \\
\hline 10 & 2 & 175416.3 & 2762887.2 & 194.22 & Little River & Ridlon Rd., DS LE \\
\hline 11 & 2 & 175465.2 & 2762765.2 & 194.10 & Little River & Ridlon Rd., DS RE \\
\hline 15 & 1 & 172435.9 & 2757937.0 & 175.12 & Little River & Hubbard Rd., DS RE 1 \\
\hline 16 & 1 & 172439.0 & 2757937.4 & 175.16 & Little River & Hubbard Rd., DS RE 2 \\
\hline 17 & 1 & 172454.5 & 2758036.6 & 175.24 & Little River & Hubbard Rd., DS RE 3 \\
\hline 18 & 5 & 182182.8 & 2760265.7 & 206.74 & Keay Brook & Ridlon Rd., US LE \\
\hline 19 & 5 & 182014.4 & 2760215.9 & 203.82 & Keay Brook & Ridlon Rd., DS LE \\
\hline 20 & 5 & 182225.6 & 2760177.4 & 207.79 & Keay Brook & Ridlon Rd., US RE \\
\hline 21 & 6 & 177044.8 & 2756695.3 & 189.31 & Keay Brook & Hubbard Rd., US LE \\
\hline 22 & 6 & 177133.0 & 2756700.4 & 189.44 & Keay Brook & Hubbard Rd., US RE \\
\hline 23 & 6 & 177004.3 & 2756460.0 & 187.97 & Keay Brook & Hubbard Rd., DS LE \\
\hline 30 & 8 & 213479.0 & 2822174.0 & 170.59 & Mousam River & Whicher's Mill Rd., US RE 4 \\
\hline 31 & 8 & 213476.7 & 2822203.2 & 170.83 & Mousam River & Whicher's Mill Rd., US RE 5 \\
\hline 32 & 7 & 208181.7 & 2841425.2 & 87.01 & Mousam River & Mill St.(near Rt. 99), DS LE 1 \\
\hline 33 & 7 & 208171.4 & 2841453.3 & 87.16 & Mousam River & Mill St.(near Rt. 99), DS LE 2 \\
\hline 34 & 7 & 208163.7 & 2841476.2 & 87.03 & Mousam River & Mill St.(near Rt. 99), DS LE 3 \\
\hline 35 & 7 & 208168.0 & 2841477.9 & 87.04 & Mousam River & Mill St.(near Rt. 99), DS LE 4 \\
\hline 36 & 24 & 201296.5 & 2852892.8 & 26.62 & Mousam River & Rt. 1, DS LE \\
\hline 37 & 25 & 182424.5 & 2845129.7 & 46.86 & Blacksmith Brook & Rt. 1, US LE \\
\hline 38 & 25 & 182362.6 & 2845258.8 & 42.13 & Blacksmith Brook & Rt. 1, DS LE \\
\hline 39 & 23 & 199159.7 & 2842027.0 & 51.17 & BranchBrook & Rt. 9A (old gage), DS LE 1 \\
\hline 40 & 23 & 199160.9 & 2842035.5 & 51.50 & BranchBrook & Rt. 9A (old gage), DS LE 2 \\
\hline 41 & 23 & 199268.7 & 2841936.2 & 53.43 & BranchBrook & Rt. 9A (old gage), US RE 3 \\
\hline 42 & 23 & 199288.0 & 2841932.6 & 53.33 & BranchBrook & Rt. 9A (old gage), US RE 4 \\
\hline
\end{tabular}


Table 1. Peak water-surface elevations for May 2006 flood in York County, Maine.-Continued

[Northings and Eastings referenced to Maine State Plane West, North American Datum 1983; Elevations referenced to North American Vertical Datum of 1988; Ave, avenue; BR, bridge; DS, downstream; HWM, high-water mark; I-95, Interstate 95; LE, left edge of water (when facing downstream); Num., number; R., ID, identification; river; Rd., road; RE, right edge of water; RR, railroad; Rt., route; St. street; US, upstream; WS, water-surface elevation at time of survey, not a high-water mark]

\begin{tabular}{|c|c|c|c|c|c|c|}
\hline $\begin{array}{l}\text { Point } \\
\text { ID }\end{array}$ & $\begin{array}{c}\text { Site } \\
\text { number }\end{array}$ & Northing & Easting & Elevation & Waterbody & Location, description \\
\hline 43 & 11 & 172981.7 & 2800865.6 & 124.88 & Great Works River & Canal St. Dam above Rt. 9, US LE 1 \\
\hline 45 & 10 & 171109.8 & 2800922.4 & 110.34 & Great Works River & Madison St., DS LE \\
\hline 46 & 12 & 151299.4 & 2803352.1 & 97.16 & Great Works River & “Emery’s Bridge” @Hooper’s Rd., US RE \\
\hline 47 & 12 & 151294.6 & 2803321.1 & 97.22 & Great Works River & "Emery’s Bridge" @Hooper's Rd., DS RE 1 \\
\hline 49 & 12 & 151236.1 & 2803405.7 & 97.09 & Great Works River & “Emery’s Bridge” @Hooper's Rd., US LE 3 \\
\hline 50 & 13 & 140094.7 & 2786233.9 & 83.10 & Great Works River & Rt. 236, US LE \\
\hline 51 & 13 & 140056.7 & 2786140.1 & 83.33 & Great Works River & Rt. 236, DS LE \\
\hline 52 & 14 & 141059.1 & 2784972.7 & 81.66 & Great Works River & Brattle St.Dam, US RE \\
\hline 53 & 15 & 157611.5 & 2829183.5 & 91.42 & Ogunquit River & N. Village Rd., DS RE \\
\hline 57 & 16 & 158239.2 & 2832400.7 & 72.81 & Ogunquit River & I-95, DS RE 1 \\
\hline 58 & 16 & 158272.3 & 2832433.6 & 72.77 & Ogunquit River & I-95, DS RE 2 \\
\hline 59 & 16 & 158287.6 & 2832447.3 & 72.65 & Ogunquit River & I-95, DS RE 3 \\
\hline 60 & 17 & 159768.0 & 2837834.9 & 43.65 & Ogunquit River & Rt.1, US RE \\
\hline 61 & 17 & 159806.6 & 2837991.9 & 34.91 & Ogunquit River & Rt.1, DS LE \\
\hline 62 & 21 & 186318.4 & 2847377.3 & 24.03 & Merriland River & RR bridge US of Rt.1, DS RE 1 \\
\hline 63 & 21 & 186299.2 & 2847370.8 & 24.19 & Merriland River & RR bridge US of Rt.1, DS RE 2 \\
\hline 64 & 21 & 186282.3 & 2847407.4 & 24.15 & Merriland River & RR bridge US of Rt.1, DS RE 3 \\
\hline 65 & 21 & 186372.1 & 2847278.7 & 25.18 & Merriland River & RR bridge US of Rt.1, US RE 1 \\
\hline 72 & 18 & 131225.4 & 2831959.3 & 20.28 & Cape Neddick River & Rt. 1, DS RE 3 \\
\hline 73 & 18 & 131222.9 & 2831949.3 & 20.94 & Cape Neddick River & Rt. 1, DS RE 4 \\
\hline 74 & 18 & 131209.5 & 2831889.2 & 26.39 & Cape Neddick River & Rt. 1 , US RE 1 \\
\hline 75 & 18 & 131225.4 & 2831882.5 & 26.16 & Cape Neddick River & Rt. 1, US LE 1 \\
\hline 76 & 18 & 131220.4 & 2831874.2 & 26.35 & Cape Neddick River & Rt. 1, US LE 2 \\
\hline 77 & 19 & 124664.8 & 2834168.4 & 11.83 & Briley Brook & $\begin{array}{l}\text { Bay St.(650' West of York's Short Sand's Beach), } \\
\text { HWM } 1\end{array}$ \\
\hline 78 & 19 & 124654.0 & 2834152.9 & 11.87 & Briley Brook & $\begin{array}{l}\text { Bay St.(650'West of York's Short Sand's Beach), } \\
\text { HWM } 2\end{array}$ \\
\hline 79 & 20 & 115737.6 & 2830119.4 & 12.98 & Little River & $\begin{array}{l}\text { Bayview Ave. off Long Sand's Rd.(145' West of Rt. 1) } \\
\text { HWM } 1\end{array}$ \\
\hline 80 & 20 & 115748.2 & 2830131.8 & 13.00 & Little River & $\begin{array}{l}\text { Bayview Ave. off Long Sand's Rd.(145' West of Rt. 1) } \\
\text { HWM } 2\end{array}$ \\
\hline
\end{tabular}


the type of bridge. The embankment slopes for the entrance and exit are measured, and the location, type, and size of any guide banks, wing walls, and abutments are measured. In addition to cross-section surveys and collection of bridge structure information, the downstream river slope is computed, and channel and floodplain roughness values are estimated (Matthai, 1967).

The geometric survey data were entered in the U.S. Army Corp of Engineers step-backwater computer program HEC-RAS. The one-dimensional steady flow water-surface profile computation component of HEC-RAS was used in the analysis. A range of flows, 2-year to 500-year recurrence interval flows, and a flow 50 percent greater than the 500-year flow were entered into the model. Each flow generated an independent hydraulic profile. The profiles provided guidance to calibrate the model. After calibration, flows were selected and input into the model so that the resulting water-surfaceelevation output from HEC-RAS matched the high-water marks that were observed for this study (table 1) at the downstream exit cross sections and the upstream approach cross sections (U.S. Army Corps of Engineers, 2004).
A sensitivity analysis was performed on the final calibrated models. The boundary condition of slope was set, and energy-loss characteristics (including channel roughness, and contraction and expansion coefficients) were modified to determine the effects of these changes on the resulting watersurface elevations and the final computed flows (Chow, 1959). In addition to the computed 2006 floodflow, the hydraulic profiles (with recurrence intervals from 2 years to greater than 500 years) were reviewed to determine the stability of the model.

\section{Peak Flows}

Peak flows were calculated for nine different locations in York County for the May 2006 flood (table 2). Seven of the flows were calculated using an indirect method and two flows were calculated using a rating extension technique. The location of the sites with peak-flow determinations and their associated recurrence intervals are shown in plate 1. Recurrence intervals are discussed in the Peak-Flow Recurrence Intervals section of this report.

Table 2. Peak flows calculated for the May 2006 flood and peak flows for 10-, 50-, 100-, and 500-year flood recurrence intervals in York County, Maine.

[>, greater than; $\mathrm{mi}^{2}$, square mile; $\mathrm{ft}^{3} / \mathrm{s}$, cubic feet per second]

\begin{tabular}{|c|c|c|c|c|c|c|c|c|}
\hline \multirow{2}{*}{$\begin{array}{l}\text { Site } \\
\text { Number }\end{array}$} & \multirow{2}{*}{ Stream and location } & \multicolumn{4}{|c|}{$\begin{array}{l}\text { Peak flow }\left(\mathrm{ft}^{3} / \mathrm{s}\right) \text { for given } \\
\text { recurrence interval }\end{array}$} & \multicolumn{2}{|c|}{$\begin{array}{l}\text { Peak flow calculated } \\
\text { during May } 2006 \text { flood }^{b}\end{array}$} & \multirow{2}{*}{$\begin{array}{c}\text { Drainage } \\
\text { area } \\
\left(\mathrm{mi}^{2}\right)\end{array}$} \\
\hline & & 10-year & 50-year & 100-year & 500-year & $\begin{array}{l}\text { Peak flow } \\
\left(\mathrm{ft}^{3} / \mathrm{s}\right)\end{array}$ & $\begin{array}{l}\text { Recurrence } \\
\text { interval }\end{array}$ & \\
\hline 3 & Little River at Long Swamp Road, Berwick & 1,630 & 2,310 & 2,630 & 3,380 & 3,390 & $>500$-year & 51.3 \\
\hline 6 & Keay Brook at Hubbard Road, Berwick & 457 & 673 & 775 & 1,020 & 1,120 & $>500$-year & 11.3 \\
\hline 8 & $\begin{array}{l}\text { Mousam River near West Kennebunk (USGS } \\
\text { streamflow gaging station number 01069500) }\end{array}$ & $2,470^{c}$ & $3,600^{c}$ & $4,100^{c}$ & $5,470^{c}$ & 6,100 & $>500$-year & 98.9 \\
\hline 12 & $\begin{array}{l}\text { Great Works River at Emery's Bridge on } \\
\text { Hooper's Sand Road, South Berwick }\end{array}$ & 2,130 & 3,020 & 3,430 & 4,420 & 6,460 & $>500$-year & 64 \\
\hline 21 & $\begin{array}{l}\text { Merriland River at RR bridge above State } \\
\text { Route } 1 \text {, Kennebunk }\end{array}$ & 385 & 547 & 623 & 800 & 2,240 & $>500$-year & 15.4 \\
\hline 23 & $\begin{array}{l}\text { Branch Brook near Kennebunk (USGS } \\
\quad \text { streamflow gaging station number 01069700) }\end{array}$ & $600^{c}$ & $978^{\mathrm{c}}$ & $1,160^{c}$ & $1,640^{\mathrm{c}}$ & 1,500 & $\begin{array}{l}\text { 100- to } \\
\text { 500-year }\end{array}$ & 10.3 \\
\hline 25 & Blacksmith Brook at State Route 1, Wells & 116 & 178 & 208 & 280 & 473 & $>500$-year & 2.2 \\
\hline
\end{tabular}

${ }^{a}$ Computed using regression equations estimates published in Hodgkins (1999).

${ }^{\mathrm{b}}$ Computed using indirect methods.

${ }^{c}$ Flows computed using Log Pearson type III estimates published in Hodgkins (1999). 


\section{Peak-Flow Recurrence Intervals}

The recurrence interval is the average period of time between peak flows that are greater than or equal to a specified magnitude. For example, the 50 -year peak flow is the flow that would be exceeded or equaled, on long-term average, once in 50 years. This does not imply that flooding will happen at regular intervals. Two 50-year peak flows could occur in 2 consecutive years or even the same year. In contrast, a 50-year peak flow might not occur for 100 years. The reciprocal of the recurrence interval is called the annual exceedance probability; that is, the probability that a given peak flow will be exceeded or equaled in any given year. For example, the annual exceedance probability of the 50-year peak flow is 0.02 . In other words, there is a 2 percent chance that the 50-year peak flow will be exceeded or equaled in any given year.

The 500-, 100-, 50-, and 10-year recurrence-interval peak flows for sites in table 2 were determined as explained below. The peak flows from the May 2006 flood were then compared to these recurrence-interval peak flows to determine the recurrence intervals of the May 2006 peak flows. All recurrence interval estimates have an uncertainty associated with them. The uncertainty generally increases as the recurrence interval increases. Recurrence intervals that are greater than 100 years have a large amount of uncertainty associated with them (Interagency Advisory Committee on Water Data, 1982).

The recurrence-interval peak flows for seven sites in this study without historical peak-flow data were calculated using the regression equations presented in Hodgkins (1999). These regression equations were developed using generalized least squares regression procedures based on data from 70 USGS streamflow gaging stations in Maine and eastern New Hampshire. The final explanatory variables used in the equations were drainage area and percentage of basin wetlands. The equations were generated using drainage areas ranging from 0.9 to $1,650 \mathrm{mi}^{2}$ with basin wetlands ranging from 0.7 percent to 26.7 percent of the drainage area. The recurrence-interval peak flows for Branch Brook near Kennebunk and Mousam River near West Kennebunk, which have historical peak-flow data, were published previously by Hodgkins (1999). Additional peak-flow data have not been collected at these sites since the Hodgkins (1999) report was published, and thus the recurrence-interval peak flows recorded in Hodgkins (1999) were used for the analysis in this study. Peak-flow recurrence intervals for eight of the nine streams studied were calculated to be greater than 500-years. The peak-flow recurrence interval of the remaining stream was calculated to be between a 100 -year and 500-year interval.

\section{Historical Perspective on Flood}

Accurate flood-damage information is difficult to obtain. In most cases, the total flood damage is never known. As a result of calculated damages to specific types of property, a presidential disaster declaration was made on May 25, 2006, for York County, Maine. Public flooding damages for York County are estimated to be $\$ 7.5$ million. (Maine Emergency Management Agency, written commun., 1996). In retrospect, flood-damage data can be used as a measure of the effectiveness of attempts to mitigate flood hazards and to place an individual flood into historical perspective. Documented data on peak flows and high water marks from the May 2006 event can be used in the future for assessing the flood from a historical perspective.

\section{Historical Peak Flows}

Minimal historical peak-flow data are available for much of southern Maine, especially York County. The USGS operated a continuous-record streamflow gaging station at the Mousam River at Wicher's Mill Road near West Kennebunk, Maine, from 1939 to 1984 . The highest peak flow recorded during that time was 4,030 ft $3 / \mathrm{s}$ in March 1983. A peak flow of $3,600 \mathrm{ft}^{3} / \mathrm{s}$ during the flood of October 1996 was documented outside of the period of continuous record (Hodgkins and Stewart, 1997). On the basis of 45 years of continuous record, assuming all large floods from 1985 to 2005 were documented, the May 2006 flow of $6,100 \mathrm{ft}^{3} / \mathrm{s}$ is the highest documented flow at this site from 1939 to 2006 . The USGS operated a streamflow gaging station on Branch Brook near Kennebunk, Maine, from 1964 to 1974 that was designed to record all annual peak flows. The highest peak recorded during that time was $723 \mathrm{ft}^{3} / \mathrm{s}$ in 1972 . From 1975 to 2005 , the highest documented peak flow was $1,020 \mathrm{ft}^{3} / \mathrm{s}$ during the flood of October 1996. On the basis of 11 years of continuous peak-flow record, assuming all large floods from 1975 to 2005 have been documented, the May 2006 flow of $1,500 \mathrm{ft}^{3} / \mathrm{s}$ is the highest documented flow at this site from 1964 to 2006.

For the other seven locations where flows were determined by indirect methods, historical streamflow records are not available. A general comparison to theoretical maximum floods is possible however. Crippen and Bue (1977) determined envelope curves relating empirical maximum peak flows to drainage area to provide a guide for estimating the magnitude of maximum floodflows that can be expected at a given site on a stream; the curves are plotted in log space with the drainage area plotted on the $\mathrm{x}$-axis and the flow on the y-axis. The curves were developed by analyzing thousands of sites with recorded floodflows, then using the sites with the most extreme flows to draw the envelope curves for 17 different regions in the United States. Maine is in region 1 (region 1 comprises Maine, Vermont, most of New Hampshire, most of Connecticut, western Massachusetts, and a small part of Rhode Island).

In general, all of the peak flows computed for this study plotted a similar distance below the region 1 envelope curve. The peak flow that plotted closest to the envelope curve occurred at the Ogunquit River. The peak flow that plotted 
furthest from the envelope curve occurred at Keay Brook. None of the floodflows for the Mother's Day flood reached or exceeded the potential maximum floodflow as defined by the Crippen and Bue (1977) envelope curves. The plotting positions provide evidence that the peak flow calculations for this study are reasonable and that all nine sites experienced similar amounts of runoff per unit drainage area $\left(\mathrm{ft}^{3} / \mathrm{mi}^{2}\right)$.

\section{Historical Peak Water-Surface Elevations}

Minimal historical peak water-surface-elevation data are available for much of York County, Maine. Peak elevations can be used for comparison with historical elevations at a specific location if the river channel or hydraulic structure has not changed substantially between floods. Data are available for comparison of elevations during the flood of 1996 (Hodgkins and Stewart, 1997) with those during the flood of 2006; for the site discussed below it is believed that the structure and river channel may have changed between these floods. Blacksmith Brook at Rt. 1, Wells, Maine recorded an upstream peak water-surface elevation (NAVD88) of $46.72 \mathrm{ft}$ and a downstream peak water-surface elevation of $41.42 \mathrm{ft}$ for the 1996 flood. The peak water-surface elevation recorded during the May 2006 event, upstream from the site, was $46.86 \mathrm{ft}$ (NAVD88), and the downstream peak water-surface elevation was $42.13 \mathrm{ft}$. The upstream peak water-surface elevations were very similar at a difference of $0.14 \mathrm{ft}$, but the downstream elevations varied by $0.71 \mathrm{ft}$. This difference may indicate that the hydraulic relation has changed sometime during the period from October 1996 to May 2006. Both sites discussed below are believed to have stable river channels and hydraulic structures between the floods. At Branch Brook near Kennebunk, Maine, the upstream peak water-surface elevation (NAVD88) was $49.92 \mathrm{ft}$, and the downstream peak water-surface elevation was $49.32 \mathrm{ft}$ for the 1996 flood; during the May 2006 flood, the upstream peak water-surface elevation (NAVD88) was $53.33 \mathrm{ft}$, and the downstream peak water-surface elevation was $51.50 \mathrm{ft}$. At Mousam River near West Kennebunk, Maine, the peak water-surface elevation (NAVD88) was $170.41 \mathrm{ft}$ for the 1996 flood, which is lower than the 2006 flood elevation of $170.66 \mathrm{ft}$ (Hodgkins and Stewart, 1997).

\section{Comparison with Existing Flood Insurance Studies}

Comparisons were made between existing Flood Insurance Study data and the May 2006 flood data. In York County, detailed Flood Insurance Studies are available for the communities of Berwick, North Berwick, Kennebunk, Kennebunkport, Ogunquit, Sanford, South Berwick, Wells, and York. The original publication dates of the studies range from 1982 to 1984; parts of many of the studies were revised during 1998 to 2003. In a detailed Flood Insurance Study, the peak water-surface elevations for selected recurrence intervals (particularly the 100-year elevations) are calculated using hydrologic and hydraulic analyses. The hydrologic analysis involves defining the flow or range of peak flows that can be expected for selected recurrence intervals. The hydraulic analysis involves computing flood elevations on the basis of physical features of a stream, such as channel geometry, bed material, and structure geometry.

Two types of comparisons were made between the Flood Insurance Studies and the May 2006 flood. At sites where the peak flow was determined for the May 2006 flood, independent analyses of hydrology and hydraulics were completed. For the May 2006 sites with a calculated peak flow, this flow was compared to the flow published in the existing Flood Insurance Study. At sites for which only peak surface-water elevations are available for the May 2006 event, only elevation comparisons were made. It was not feasible to determine the accuracy of the hydraulics or the hydrology independent of each other in the existing Flood Insurance Studies.

In a detailed Flood Insurance Study, peak flows for selected recurrence intervals (the hydrology) are input into a step-backwater hydraulic model containing the geometric data for the stream reach and other data. The model generates peak water-surface elevations at selected cross sections in the reach. The resulting elevations from many cross sections in the model, including cross sections at and near bridges, are plotted and labeled as flood profiles in the Flood Insurance Study. The 100-year and 500-year flood elevations were selected from the flood profile graph for comparison with the elevations for the May 2006 flood. For example, if the May 2006 flood elevation was measured for the point 100 feet upstream from a given structure, the elevation selected from the flood-profile plot would be 100 feet upstream from that structure.

The elevation comparison sites are on the same stream as the flow comparison sites, but at different locations. At sites where the May 2006 peak flow was not calculated, only the elevations were available for analysis. The May 2006 peak flow could be determined at many of the elevation comparison sites by a simple drainage-area correction. The peak flow also could be calculated directly from regression equations. The drainage-area adjustment calculations would yield the same results as the regression equations because the same calculations would be done on the May 2006 flow and the calculated flows for each recurrence interval. The calculation of hydrology peak flows for selected recurrence intervals for the 2006 flood using the regression equations was not done because biases from a drainage-area adjustment for the May 2006 flow would produce similar peak flows and complicate the analysis of the floodflows. 


\section{Hydrologic Analysis}

The peak flows published in the Flood Insurance Study for Sanford and South Berwick (Federal Emergency Management Agency, 1998 and 1984, respectively) were computed using the Natural Resources Conservation Services computer program TR-20 (U.S. Department of Agriculture, 1990). The 24-hour duration storm and normal antecedent moisture conditions were used in both studies to compute the range in flows for the 10-, 50-, 100- and 500-year recurrence intervals. The remaining published peak flows for Kennebunk, Ogunquit, York, and Wells (Federal Emergency Management Agency, 1982, 1983, 2003, and 2003, respectively) were computed using the equations published in Morrill (1975). These equations were used to predict flows based on drainage area, main-channel slope, and percentage of area of lakes and ponds. The equations used by Morrill have been superseded by equations in a more recent publication (Hodgkins, 1999). The floodflows calculated for this report used the updated regression equations in Hodgkins (1999), which were based on substantially more peak-flow data from Maine streams than used by Morrill and were generated using more advanced statistical techniques.

Typically, the 10-, 50-, 100-, and 500-year floodflows are published in detailed Flood Insurance Studies. FEMA regulates flood insurance policies to the 100-year floodflow and corresponding flood elevation, but the additional recurrence interval data are useful for other regulatory purposes. Only the 100-year and 500-year recurrence intervals were used in this analysis. Comparison to 10-year and 50-year

Table 3. Peak flows calculated for the May 2006 flood in York County, Maine, and peak flows from published Flood Insurance Studies for the 100- and 500-year recurrence interval events.

[NS, location not identified in study; $\mathrm{ft}^{3} / \mathrm{s}$, cubic feet per second; $\mathrm{mi}^{2}$, square mile]

\begin{tabular}{|c|c|c|c|c|c|c|c|}
\hline \multirow[b]{2}{*}{$\begin{array}{l}\text { Site } \\
\text { number }\end{array}$} & \multirow[b]{2}{*}{ Stream and location } & \multicolumn{4}{|c|}{ Peak flow $\left(\mathrm{ft}^{3} / \mathrm{s}\right)$ for given recurrence interval } & \multirow[b]{2}{*}{ Community } & \multirow[b]{2}{*}{$\begin{array}{l}\text { Drainage } \\
\text { area }\left(\mathrm{mi}^{2}\right)\end{array}$} \\
\hline & & \multicolumn{2}{|c|}{ Calculated ${ }^{\mathrm{a}}$} & \multicolumn{2}{|c|}{$\begin{array}{l}\text { Published flood } \\
\text { insurance study }\end{array}$} & & \\
\hline 8 & $\begin{array}{l}\text { Mousam River near West Kennebunk (USGS } \\
\text { streamflow gaging station number 01069500) }\end{array}$ & 4,100 & 5,470 & 4,000 & $\mathrm{~b}$ & Sanford & $99.0^{c}$ \\
\hline NS & Great Works River at Old South Berwick Road & -- & -- & 3,640 & 5,180 & South Berwick & 46.1 \\
\hline 12 & $\begin{array}{l}\text { Great Works River at Emery's Bridge on Hooper's } \\
\text { Sand Road, South Berwick }\end{array}$ & 3,430 & 4,420 & -- & -- & South Berwick & 64.0 \\
\hline NS & Great Works River at Emery's Bridge Road & -- & -- & 7,640 & 10,500 & South Berwick & 82.1 \\
\hline 18 & Cape Neddick River at US Route 1, York & 755 & 1,000 & 950 & 1,420 & York & $9.47^{\mathrm{f}}$ \\
\hline 21 & $\begin{array}{l}\text { Merriland River at RR bridge above State Route 1, } \\
\text { Kennebunk }\end{array}$ & 623 & 800 & -- & -- & Kennebunk & 15.4 \\
\hline NS & Merriland River at Lord's Road, Kennebunk & -- & -- & 1,846 & 2,757 & Kennebunk & 16.8 \\
\hline 25 & Blacksmith Brook at US Route 1, Wells & 208 & 280 & 385 & 607 & Wells & $2.20^{\mathrm{g}}$ \\
\hline
\end{tabular}

aFlow computed using Log Pearson type III estimates published in Hodgkins (1999).

b500-year flow was not published in the Sanford Flood Insurance Study.

'Drainage area from Sanford Flood Insurance Study is $102.0 \mathrm{mi}^{2}$.

dThe flows in the Wells and Ogunquit Flood Insurance Studies did not match. Ogunquit flows were used.

e Drainage area from Ogunquit Flood Insurance Study is $11.94 \mathrm{mi}^{2}$.

fDrainage area from Cape Neddick Flood Insurance Study is $9.53 \mathrm{mi}^{2}$.

gDrainage area from Blacksmith Flood Insurance Study is $2.25 \mathrm{mi}^{2}$. 
recurrence intervals were not made to limit repetition. The peak flows computed for this study and those in published Flood Insurance Studies are presented in table 3 for six sites.

On the Mousam River a direct comparison could be made only for a 100-year event using the Sanford Flood Insurance Study (Federal Emergency Management Agency, 1998). The 500-year flow was not published in the effective (existing) Flood Insurance Study for this community. The 100-year floodflow calculated for this study was almost identical to the flows published in the Flood Insurance Study. For the site at the mouth of the Mousam River (drainage area of 119 $\mathrm{mi}^{2}$ ), the 100-year and 500-year floodflows were published in the Kennebunk Flood Insurance Study (Federal Emergency Management Agency, 1982); the flows in the Flood Insurance Study are lower than those calculated for 100-year and 500-year flows in this study. The flows published in the Flood Insurance Study were calculated using regression equations from Morrill (1975). An alternate method of calculating the 100-year and 500-year floodflows would entail the use of the historical peak-streamflow record for the Mousam River near West Kennebunk (drainage area of $99 \mathrm{mi}^{2}$ ) along with a drainage-area adjustment. This calculation was done using Hodgkins equations (1999), which produced a flows similar to the peaks generated by analyzing the historical peak-streamflow record.

A direct comparison of peak streamflows could not be made for the Great Works River at Emery's Bridge (site 12). Flows published in the Flood Insurance Study were calculated for points upstream and downstream from the site used for this study on the Great Works River (table 3). For comparison, a drainage-area adjustment (Hodgkins, 1999) was made to the calculated 100-year and 500-year floodflows at site 12. The adjusted flows at site 12 were 38 percent (100-year) and 43 percent (500-year) lower than the flows upstream from this site that were published in the South Berwick Flood Insurance Study (Federal Emergency Management Agency, 1984), which were calculated using the TR-20 method. A basic drainagearea adjustment equation is

$$
Q_{\mathrm{A}}=Q_{\mathrm{B}}\left(A_{\mathrm{A}} / A_{\mathrm{B}}\right)^{c},
$$

where $Q_{\mathrm{A}}$ and $Q_{\mathrm{B}}$ equal flow at site $\mathrm{A}$ and $\mathrm{B}$, respectively, and $A_{\mathrm{A}}$ and $A_{\mathrm{B}}$ equal drainage area at site $\mathrm{A}$ and $\mathrm{B}$, respectively. The drainage-area adjustment values $(c)$ for the Great Works River (site 12) 100-year and 500-year floodflows were calculated as 1.28 and 1.22, respectively. In Hodgkins (1999), the recommended values for $(c)$ are 0.748 for the 100 -year and 0.729 for the 500-year floodflows.

For the Ogunquit River, Cape Neddick River, Merriland River, and Blacksmith Brook (sites 17, 18, 21, and 25, respectively; table 3 ), a direct comparison was made between the peak flows calculated for this study using Hodgkins (1999) and the respective peak flows published in the Flood Insurance Studies. The Merriland River peak flows were adjusted using a drainage area adjustment to make the direct comparison. At all four locations, the peak flows calculated for this study were lower than the Flood Insurance Study peak flows; the 100 -year floodflows were 21 percent to 66 percent lower and the 500-year floodflows were 30 percent to 71 percent lower.

\section{Hydraulic Analysis}

For site-specific hydraulic analyses, the peak watersurface elevations from the May 2006 flood were compared directly with the elevations published in the corresponding Flood Insurance Studies. Sixteen of the 25 sites had detailed data that could be used for analysis.

There are two major problems with selecting the elevation from Flood Insurance Study flood-profile plots. First, the elevations used on all of the flood profiles are referenced to National Geodetic Vertical Datum of 1929 (NGVD29) and the May 2006 peak elevations are referenced to the North American Vertical Datum 1988 (NAVD88). This problem was resolved by using the latitude and longitude to determine the correction and applying the correction to the NGVD29 elevations. The correction can be done using an on-line utility VERTCON (National Geodetic Survey, 1999). The second problem is the error in determining an elevation from a profile plot. Generally, changes to the water-surface profile around structures can be large. Choosing water-surface elevations at specified distances upstream or downstream from a bridge is difficult, owing to the plot scale and cross-section locations. Water-surface profiles are linear interpolations between known values at each cross section. These problems potentially introduce error into the overall comparison. The error varies depending on the rate of the change in elevation near the structure. The error can not be corrected, but knowledge of the magnitude of the possible error was taken into account when reviewing the results from this comparison.

The peak elevations selected from appropriate Flood Insurance Studies for the 100-year and 500-year flood profiles and the peak elevations for the 2006 flood are listed in table 4. The 2006 flood-peak water-surface elevations can be from a single high-water mark, or an average of two, three, or four different high-water marks for the upstream and (or) downstream side of each structure (upstream marks are averaged together and downstream marks are averaged together). The average distance upstream or downstream from a given structure was used to determine the distance used for the selected elevation from the Flood Insurance Study water-surface profiles. The differences between the Flood Insurance Study flood profile 500-year elevations and the 2006 elevations are shown in table 4. Positive differences indicate the May 2006 elevations are higher than the 500-year elevations published in the Flood Insurance Studies. Because the peak flows for all but one of the sites with calculated flows from the May 2006 flood are associated with greater than 500-year recurrence intervals, the May 2006 peak water-surface elevations were expected to be greater than the 500-year Flood Insurance Study peak water-surface elevations. When the elevation differences are not consistent with expected results, there could 
be a problem with the hydraulic model. Inaccurate values for energy losses through the structure would result in inconsistent elevation differences. These potential errors in the hydraulic model could be corrected by collecting additional information, entering the information into the model, and calibrating the model to the May 2006 flood elevations.

Data for the 2006 flood are available for five points at three sites on the Mousam River. At two of the points, the 500-year Flood Insurance Study elevations are not available for comparison. At one of the remaining three points, the differences were $0.4 \mathrm{ft}$ which indicated agreement between elevations from the 2006 flood event and the 500-year peak water-surface elevation published in the Flood Insurance Study. At the remaining two points, differences were negative, $-3.8 \mathrm{ft}$ and $-2.3 \mathrm{ft}$ (the May 2006 peak water-surface elevations were lower than the 500-year peak water-surface elevation published in the Flood Insurance Study). For the Mousam River, the 500-year peak flows from the current study are similar to those published in the Flood Insurance Study. Because the 500-year flows are similar, the negative elevation difference likely was due to excessive energy losses or errors in the geometric data in the published Flood Insurance Study hydraulic model.

For Blacksmith Brook, only two points at one site are available for analysis. The upstream difference between the 500-year peak water-surface elevation published in the Flood Insurance Study and the May 2006 peak water-surface elevation is $3.4 \mathrm{ft}$, and the downstream difference is $-0.6 \mathrm{ft}$. This indicates that insufficient energy losses may have been used in the published Flood Insurance Study hydraulic model.

Seven points at five sites on the Great Works River in two communities are available for comparison. For the two mostupstream points in North Berwick (sites 10 and 11), elevation differences are $0.5 \mathrm{ft}$ and $-0.9 \mathrm{ft}$. Both elevation differences are reasonable, given the uncertainty of hydraulic models and hydrologic methods. The remaining five points are all in South Berwick (sites 12, 13, and 14), and differences range from $-1.0 \mathrm{ft}$ to $-6.6 \mathrm{ft}$. The water-surface elevation drops through the hydraulic structures and the consistency between marks appear reasonable, indicating the published hydraulic models correctly simulate the observed differences in water-surface elevation from the May 2006 flood. The South Berwick Flood Insurance Study used substantially higher 500-year recurrence interval flows than the 2006 floodflows calculated using Hodgkins (1999). The higher Flood Insurance Study flows likely are the cause of the large negative differences in watersurface elevation.

Data from five points at three sites on the Ogunquit River are available for analysis. The differences between the May 2006 elevations and the elevations in the Flood Insurance Study range from $3.3 \mathrm{ft}$ to $6.4 \mathrm{ft}$ (table 4). For the U.S. Route 1 bridge crossing (site 17), the upstream difference is $6.4 \mathrm{ft}$ and the downstream difference is $3.3 \mathrm{ft}$. The hydrology comparison indicated that the 500-year peak flows in the Wells Flood Insurance Study (Federal Emergency Management Agency, 2003) are higher than the 500-year peak flows calculated for this study, but the Flood Insurance Study 500-year peak flow is substantially smaller than the actual peak flow for the May 2006 flood. When comparing the differences between the 100-year and 500-year profiles in the Wells Flood Insurance Study, a consistent water-surface elevation drop was observed between the upstream and downstream side of the bridge. The elevation difference at the Route 1 crossing (site 17) may indicate a problem with the losses through the structure or the 2006 floodflow was substantially larger than the modeled flows. The water-surface elevations on the flood profiles increase on the upstream side faster than the downstream side compared to the May 2006 water-surface elevations. This discrepancy indicates it is likely that insufficient energy loses were simulated in the hydraulic model in the Flood Insurance Study.

Data are available from three locations at two different sites on the Merriland River. The hydrology comparison for the Merriland River showed the largest difference between the Flood Insurance Study 500-year flow of 2,757 $\mathrm{ft}^{3} / \mathrm{s}$ at one point (table 3) and the 2006500 -year flow of $800 \mathrm{ft}^{3} / \mathrm{s}$ at another point calculated using Hodgkins (1999). The drainage areas are similar, and the 500-year floodflows should be similar. The difference in hydrology is important; if the flow in the Wells Flood Insurance Study is too great, the resulting 100-year flood elevation and mapped floodplain would be based on a flow that is too high. The elevation differences range from $-0.4 \mathrm{ft}$ to $0.5 \mathrm{ft}$ upstream and downstream from Route 1 , indicating that reasonable results were obtained from the hydraulic analysis in the Flood Insurance Study.

At one site on the Cape Neddick River at a bridge, both upstream and downstream elevations are available for comparison. The upstream difference is $6.2 \mathrm{ft}$, and the downstream difference is $0.5 \mathrm{ft}$. The hydrology comparison indicates that the York Flood Insurance Study 500-year peak flow is higher than the May 2006 500-year peak flow calculated using Hodgkins (1999), but the calculated peak flow for the May 2006 flood (table 2) is substantially larger than the 500-year peak flow in the Flood Insurance Study. This indicates it is likely insufficient energy loses were simulated in the hydraulic model in the Flood Insurance Study.

\section{Summary and Conclusions}

The flood of May 10-17, 2006 (sometimes referred to as the "Mother's Day flood"), caused widespread damage to numerous roads, structures, and property in York County, Maine. During 2006-07, the U.S. Geological Survey, in cooperation with the Federal Emergency Management Agency, collected and analyzed an extensive amount of flood data from York County to document the flood. Eighty peak water-surface elevations were marked and surveyed following the May 2006 flood. Peak flows from the flood and their associated recurrence intervals were calculated for nine streams. Eight of these calculated flows had recurrence intervals greater 
Table 4. Peak water-surface elevations during the May 2006 flood and the 100-year and 500-year elevations from published Flood Insurance Studies for York County, Maine.

[Elevations, in feet, referenced to North American Vertical Datum of 1988 (NAVD88); Ave, avenue; BR, bridge; DS, downstream; ID, Identification number; I-95, Interstate 95; LE, left edge of water (when facing downstream); Num., number; Rd., road; RE, right edge of water; RR, railroad; Rt., route; St. street; US, upstream]

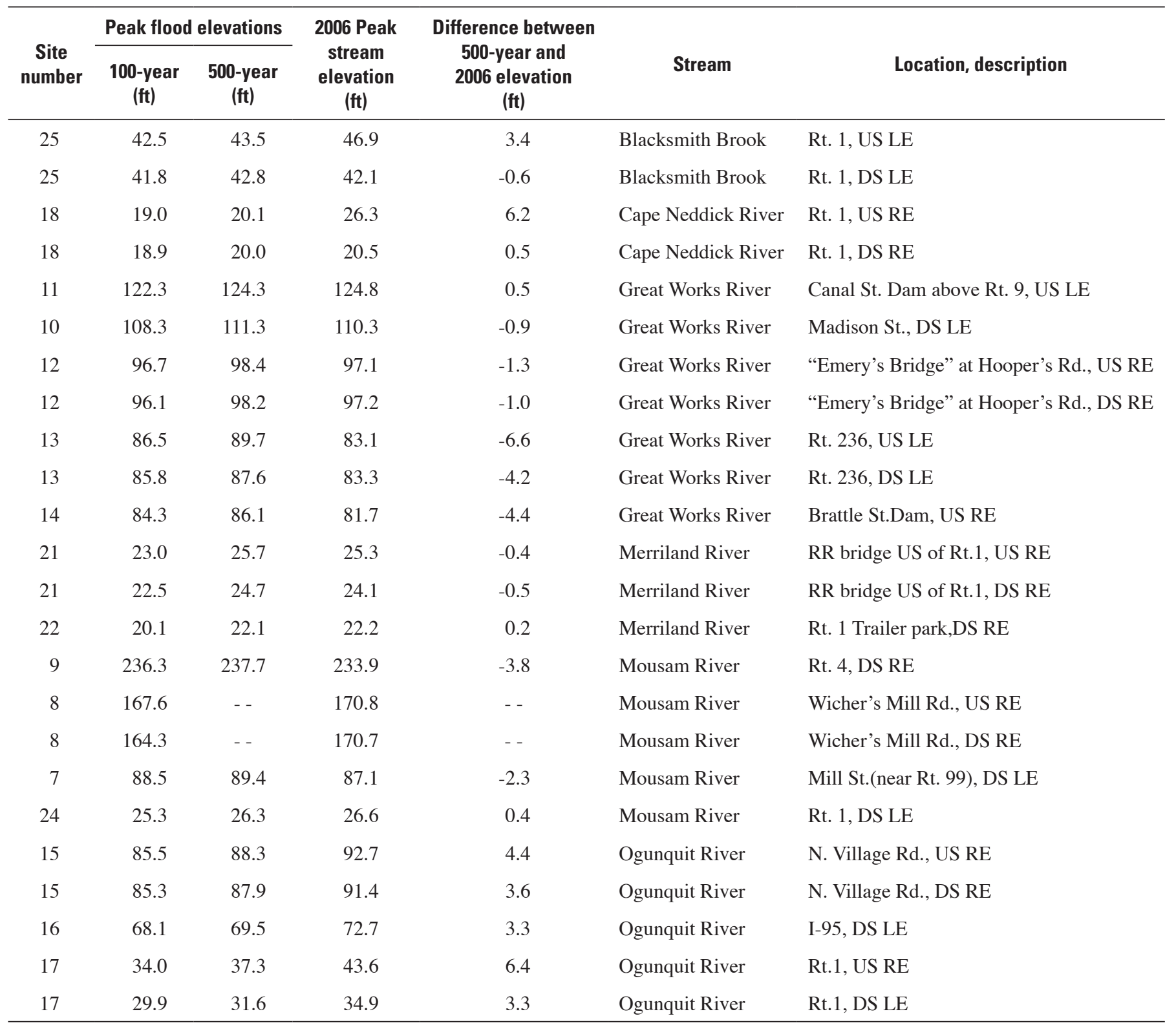


than 500 years, whereas one had a recurrence interval of 100 to 500 years. Peak-flow recurrence intervals greater than 100 years are associated with a large amount of uncertainty due to the limited number of years of record.

Floodflows can result from the interrelation of rainfall, rainfall intensity, antecedent drainage-basin conditions, physical drainage-basin characteristics, and other factors. The flood of May 2006 was a direct result of extreme rainfall; 10 to greater than 15 inches of rain were recorded in York County during May 10-17, 2006. The average rainfall received in York County during this storm exceeded the 100-year recurrence interval for 2-day, 4-day, 7-day, and 10-day rainfall totals at many locations throughout southern York County (especially Cape Neddick, Eliot, and Sanford).

The hydrologic (computation of peak flows for selected recurrence intervals) and hydraulic (computation of water-surface elevations based on selected peak flows using hydraulic models) results from published Flood Insurance Studies were compared with values calculated for this study. At sites on several streams, differences were observed between peak flows published in Flood Insurance Studies and those calculated for this study. Multiple methods were used for the Flood Insurance Study hydrology calculations. Revised regression equations for estimating peak flows of selected recurrence intervals have been generated using additional data collected since the publication of many of the Flood Insurance Studies. Use of these revised equations in this study may account for many of the differences in values between this study and the Flood Insurance Studies. The differences in the peak flows between the published Flood Insurance Studies and the flows calculated for this report are within an acceptable range for flows calculated at ungaged locations, with the exception of those for the Great Works River and Merriland River. For sites on the Mousam River, Blacksmith Brook, Ogunquit River, and Cape Neddick River, watersurface elevations from Flood Insurance Studies differed with documented water-surface elevations from the 2006 flood. A suggestion for future work is to revise selected Flood Insurance Studies for York County to incorporate additional data collected since their publication.

\section{Acknowledgments}

Meteorological data, high-water marks, photographs, damage assessments, and other supporting documents were provided by the National Weather Service, Maine Emergency Management Agency, Maine Department of Transportation, and the Town of York. This report is the culmination of an intensive effort by dedicated personnel of the U.S. Geological Survey (USGS). The following USGS employees provided substantial help by collecting and analyzing the data and in preparation of the report: Andrew R. Cloutier, Lance H. Chapman, Robert W. Dudley, Jason J. Guerrete, Glenn A. Hodgkins, Pamela J. Lombard, Garrett E. Luszcski, and Martha G. Nielsen.

\section{References Cited}

Benson, M.A., and Dalrymple, Tate, 1967, General field and office procedures for indirect discharge measurements: U.S. Geological Survey Techniques of Water-Resources Investigations, book 3, chap. A1, $30 \mathrm{p}$.

Chow, V.T., 1959, Open-channel Hydraulics: New York, McGraw-Hill, 680 p.

Crippen, J.R., and Bue, C.D., 1977, Maximum floodflows in the conterminous United States: U.S. Geological Survey Water-Supply Paper 1887, 52 p.

Dalrymple, Tate, and Benson, M.A., 1968, Measurement of peak discharge by the slope area method: U.S. Geological Survey Techniques of Water-Resources Investigations, book 3, chap. A2, 12 p.

Federal Emergency Management Agency, 1983, Flood Insurance Study, Village of Ogunquit, Maine, York County: January 5 .

Federal Emergency Management Agency, 1982, Flood Insurance Study, Town of Kennebunk, Maine, York County: July 19.

Federal Emergency Management Agency, 1984, Flood Insurance Study, Town of North Berwick, Maine, York County: August 1.

Federal Emergency Management Agency, 1998, Flood Insurance Study, Town of Sanford, Maine, York County: July 20.

Federal Emergency Management Agency, 1984, Flood Insurance Study, Town of South Berwick, Maine, York County: December 5.

Federal Emergency Management Agency, 2003, Flood Insurance Study, Town of Wells, Maine, York County: January 16.

Fontaine, R.A., and Nielsen, J.P., 1994, Flood of April 1987 in Maine: U.S. Geological Survey Water-Supply Paper 2424, $50 \mathrm{p}$.

Hodgkins, G.A., 1999, Estimating the magnitude of peak flows for streams in Maine for selected recurrence intervals: U.S. Geological Survey Water-Resources Investigations Report 99-4008, 45 p.

Hodgkins, G.A., and Stewart, G.J.,1997, Flood of October 1996 in Southern Maine: U.S. Geological Survey WaterResources Investigations Report 97-4189, 28 p.

Interagency Advisory Committee on Water Data, 1982, Guidelines for determining flood flow frequency: Water Resources Council Bulletin 17B, 28 p. 
Matthai, H.F., 1967, Measurement of peak discharge at width contractions by indirect methods: U.S. Geological Survey Techniques of Water-Resources Investigations, book 3, chap. A4, 44 p.

Morrill, R.A., 1975, A technique for estimating the magnitude and frequency of floods in Maine: U.S. Geological Survey Open-File Report 75-292.

National Geodetic Survey, 1999, Height Conversion Methodology, accessed April 15, 2008, at http://www.ngs.noaa.gov/ TOOLS/Vertcon/vertcon.html.

National Oceanic and Atmospheric Administration, Climatological Data, New England, September 1996-May 2006: National Climatic Data Center, v. 108, nos. 9-10.

Rantz, S.E., and others, 1982, Measurement and computation of streamflow: U. S. Geological Survey Water-Supply Paper 2175, 2 v., $631 \mathrm{p}$.

U.S. Department of Agriculture, Natural Resources Conservation Service, 1990, Technical Release No. 20, Computer Program, Project Formulation, Hydrology: Washington D.C.

U.S. Army Corps of Engineers, 2004, HEC-RAS River Analysis System Version 3.1.2: Hydrologic Engineering Center, accessed September 19, 2006, at http://www.hec.usace. army.mil/.

Wilks, D.S., and Cember, R.P., 1993, Atlas of precipitation extremes for the Northeastern United States and Southeastern Canada: Cornell University, Northeast Regional Climate Center, $40 \mathrm{p}$. 
Flood of May 2006 in York County, Maine 
For additional information, write to:

Director

U.S. Geological Survey

Maine Water Science Center

196 Whitten Road

Augusta, ME 04330

or visit our Web site at:

http://me.water.usgs.gov/ 
